出する結晶を滤取, 水洗, 乾燥すると $\mathrm{mp} 218$ 222。 の結晶 $1.5 \mathrm{~g}(90 \%)$ が得ら水る. 本㽞を 10\%水酸化子 トリウム溶液 $7.5 \mathrm{cc}$ 己 1 時閒加熱後 $15 \mathrm{cc}$ の水を加え酢酸で中和, 析出する結晶をアルコールから再結晶乙 $\mathrm{mp} 214^{\circ}$ の血色針獎晶. 本品は $N^{1}$ (o-xyloyl)-sulfanilamide と混融しても融点降下せず. $\mathrm{C}_{15} \mathrm{H}_{16} \mathrm{O}_{2} \mathrm{~N}_{2} \mathrm{~S}$ 計算值 C 59.19, H 5.30, N 9.21, 实験値 C $58.90, \mathrm{H} 5.58, \mathrm{~N} 9.35$.

$N^{1}, N^{4}$-Diacetyl-sulfanilamide (VI) $2.1 \mathrm{~g}$, phenyl acetate $1.3 \mathrm{~g}$ 及び無水炭酸カリウム $2 \mathrm{~g} の$ 混合物

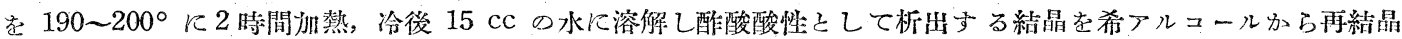
乙 $\mathrm{mp} \mathrm{252} 253^{\circ}$ (decomp) の無色針狀絬晶. 收量 $1.3 \mathrm{~g}(60 \%) . \mathrm{C}_{10} \mathrm{H}_{12} \mathrm{O}_{4} \mathrm{~N}_{2} \mathrm{~S}$ 計算值 C 46.86, H 4.71, $\mathrm{N} 10.93$, 实験值 C $46.78, \mathrm{H} 4.87, \mathrm{~N} 10.95$.

$N^{1}$-Acetyl-sulfanilamide. (VII) $1.7 \mathrm{~g}$ (0.01 モル), phenyl acetate $1.3 \mathrm{~g}$ 及び無水炭訟カリウム3 $\mathrm{g}$ (0.023 モル) の混合物を $140 \sim 150^{\circ}$ K2 時間加熱, 冷後水 $10 \mathrm{cc}$ に溶解，酢酸で中和乙析出する結晶を濾取し

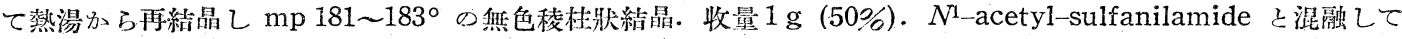
も敲点降下せず. $\mathrm{C}_{8} \mathrm{H}_{10} \mathrm{O}_{3} \mathrm{~N}_{2} \mathrm{~S}$ 計算值 $\mathrm{C} 44.84, \mathrm{H} 4.70$, 实験值 $\mathrm{C} 44.58, \mathrm{H} 5.01$.

$N^{1}$-(Dimethyl-acrylyl)-sulfanilamide (VI) $2.1 \mathrm{~g}$, phenyl dimethylacrylate $1.7 \mathrm{~g}$ 及び無水炭酸カリ ウム $2.5 \mathrm{~g}$ の混合物を $160 \sim 170^{\circ}$ に 2 晴間加熱，冷後水に溶かし，エーテルで洗い，酢酸で币和，析出する結 晶を滤取すると, $\operatorname{mp~} 215^{\circ}$ 附近の結晶 $1.5 \mathrm{~g}(60 \%)$ を得. この粗結晶を $10 \%$ 水陵化ナトリウム溶液で鹼化し mp 171 $173^{\circ}$ の舆色杜彇晶. $\mathrm{C}_{11} \mathrm{H}_{14} \mathrm{O}_{3} \mathrm{~N}_{2} \mathrm{~S}$ 計算值 C 51.95, H 5.54, 実験值 C 51.64, H 5.51.

武田薬品工業株式会社研究所

\title{
Summary
}

Heating aromatic sulfonamides with phenyl or naphthyl esters of carboxylic acids in the presence of alkali carbonate gives easily and in a good yield $N$-acyl derivatives of sulfonamides.

(Received July 23, 1951)

403. 上柳次三郎：クロルアンフェニコール合成研究（第 8 報*）有機酸による 1-p-Nitropheny1-2-amino-1,3-propanediol のアシル化

Jisaburo Ueyanagi: Studies on Chloramphenicol. VIII. Acylation of 1-p-Nitropheny1-2-amino-1,3-propanediol with Organic Acids.

(Research Lakoratory, Takeda Pharmaceutical Industries, Ltd.**)

著者は先に新方洗によるクロルアンフェニュール (II) の合成に当り 1-p-nitrophenyl-2-amino-1,3-propanediol (I) (以下 aminodiol (I) と略す) の $N$-ジクロルアセチル化を磼立するため, 先ず threo 系 $d l$-aminodiol (I) をブタノール中, 過剩のジクロル酶酸と加熱して $d l$-クロルアンフェニュール (II) を合成し,1) 本 法を更に光学的活性体即ち $d$-及び $l$-aminodiol $(d-\mathrm{I}),(l-\mathrm{I})$ にも桩張して, それぞれから天然型クロルアンフエ ニコール ( $d$-II) 及びその対掌体 $(l-$ II $)$ を收得した.2) しかし，この際ブタノールが單に溶媒としての効果を現 わすに止まらないことが予想されたので, この椣反應について多少研究を進め, 若干の知見を得たので妶に報告 宁。

aminodiol (I）の N-アシル化についてはェステルによるす法3)4) 及び酸無水物又は酸塩化物を反應させ其 の際副生する $O, N$-アシル体を選択的に加水分解して $N$ アシル体に到澾する方法があるが, 有機酸によるアシル 化については未だ報告されていない。

* 日本薬学会近畿䒝部 12 月例会 1950 年 12 月 16 日発表 (京都大学) : 第 7 報 本誌 71, 781 (1951).

** Jyuso-Nishino-machi, Osaka.

1) 立阙他：本誌 71，604 (1951)。

2) 立岡他: 本誌 71，612 (1951).

3) J. Controulis, M. C. Rebstock, H. Crooks : J. Am. Chem. Soc. 71, 2463 (1949).

4) M. C. Rebstock: J. Am. Chem. Soc. 72, 4800 (1950). 
從來アミンを遊離の有機酸と反隹させてアシルアミノ体を生成させること6) 及びアルコールを遊離の有機酸と 反應させてェステルを作ること7）は勿論知られている，又アミノアルコールを有機酸と比較的高温に憼してオキ

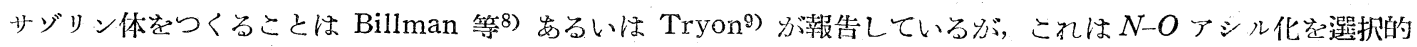
に行らことを取扱つているのではない。

前記 aminodiol（I）とジクロル釄酸とのブタノール中での反隹で收得されたものはクロルアンフェニコール

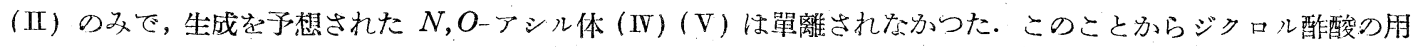
量とブタノールの存在が生成物に影響を及ぼしていることが考えられる。そこで先ずブタノールを用いずに過剩 のジクロル釄酸と aminodiol (I) を 130 140 加熱したところクロルケンフェニコールの生成は認められず,

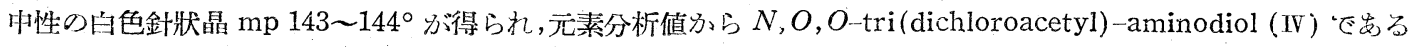
ことが分つた。炏にブタノール添加の場合, ジクロル酿酸の用量が生成物とどんな関係にあるかを見るため aminodiol (I) 1 モルに封しジクロル醀酸の量を 1〜 3 モルの閒で種々変化させ，ブタノール中で加熱し，Oーアシ ル体 (IV), (V) の有無及びクロルアンフェニュール (II) の收量を檢討したが, クロルアンフェニュール(II) の收量は 8 時間加熱の場合には常に一定 (47\%) ᄂ, $N, O$-ジクロルアセチル体 (IV), (V)の生成は認められ す, aminodiol (I) の残余は未反隹物として回收された. 他方ジクロル酶酸が 1.5 モル上上の場合にはジクロ ル酢酸ブチルェステル (VI) となることが分つた。次に $d l$-aminodiol のジクロル酢酸塩 (III) 走單離し， 之を ブタノール中で加熱した所，塩さ單離しない場合と同一つ收率で dlークロルアンフェニコール (II) 名得られた。 以上の事実からジクロル酢酸による $N$-アシル化の反應機棈はアミノ体と酸が中間に塩を形成し，これぶ加熱に よつて脫水吉も的考光られる。

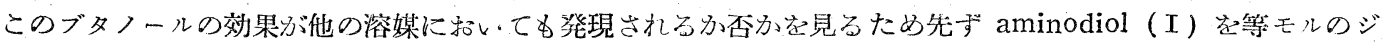
クロル酢酸とトルェン中で加熱したところクロルアンフェニコール (II) が得られたが, aminodiol (I) 1 モル とジクロル酢酸 3 モルと苍トルン中で加熱した場合にはクロルアンフェニコール (II)の生成は認めら扎ず, mp 142〜 143の色針狀晶ふ得られ，これは無溶媒の際に得られた $N, O, O$-tri (dichloroacetyl)-aminodiol (IV) で女ることが分つた.

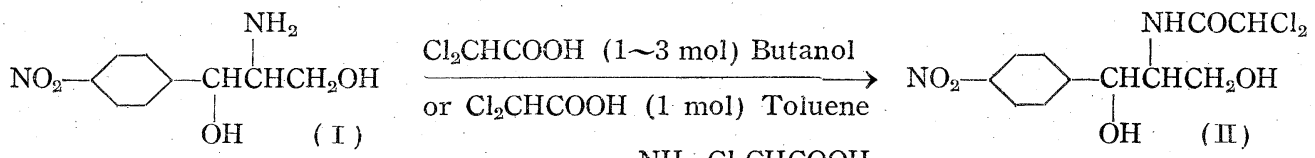<smiles>CCOC(=O)C(Cl)Cl</smiles>

(VI)

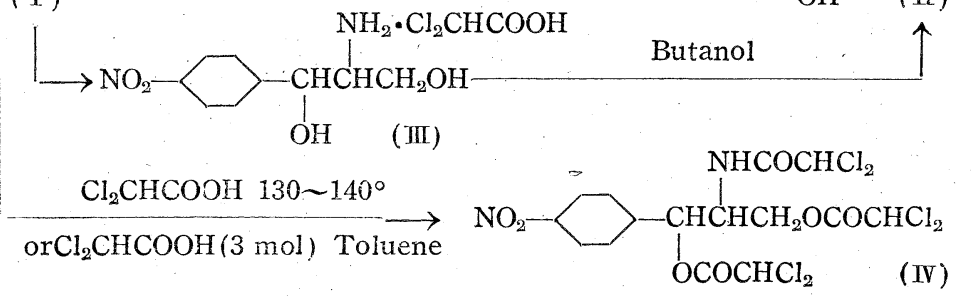

以上の結果からブタノールは，これが存在しふい場合又はトルェンのよ5な溶媒の存在で行われる を防止し，ジクロル酰酸が過剩の場合でも選択的にN-アシル化の久行わせる效果を持つていることが分る。そし てN-アシル化は中間に生成する塩が脫水されて起ると考えられ, 当量のジクロル醀酸を使用すればトルエン中て も $N$-アシル化の目的を達し得る.

5) パークデビス社：特許公告, 1950 年 2880 号.

6) L. Houben: "Method der org. Chem." IV, $380 . \quad$ 7) Ibid. II, 646.

"8) Billman, Parker: J. Am. Chem. Soc. 67, 1059 (1945).

9) Philip. F. Tryon: U. S. Pat. 2,504,951; C. A. 44, 6887 (1950). 
以上の結果を他の酸に礁用することを企てて，先ずアシル化で最も普通なアセチル化を檢討する目的で䤏酸の

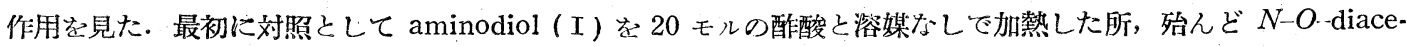

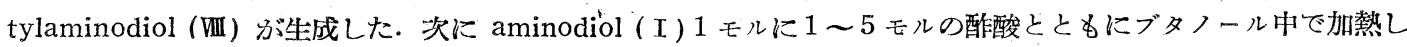
た所 $N$-acetylaminodiol (VII) が醮酸の量に無関係に 50 60\% の收量で得られ $O, N$-diacetylaminodiol (VIII) は單離されなかつた.ブタノールをトルェンに代之酶酸 1 モルを反㗹させると $N$-acetylaminodiol (VII) が生成 するが，䣲酸 5 モルの場合には $N$-aetylaminodiol (VII) の外に $N, O$-diacetylaminodiol (VII) が副生するため か,ブタノールの場合に比較して純品起得難い.

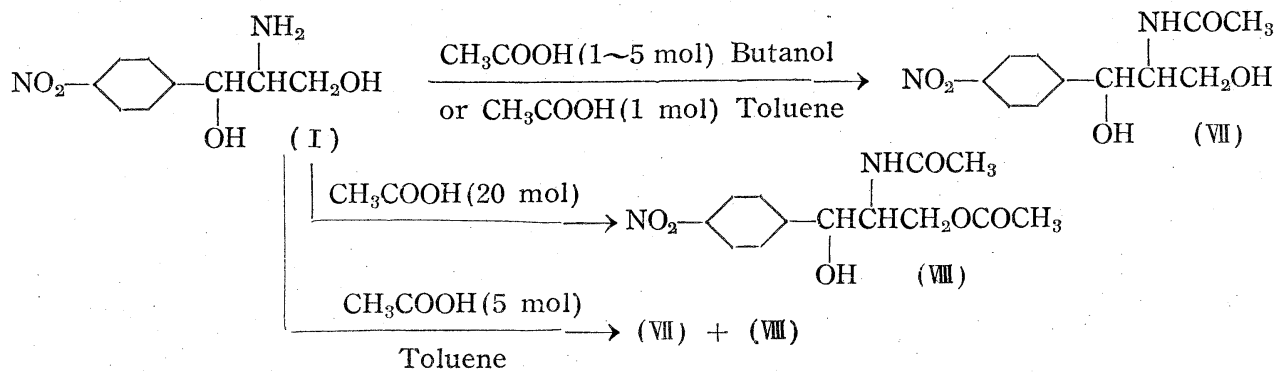

以上の結果ブタノールは前記ジクロル酫酸の場合に抢けると同樣單に溶媒としての効果を現わすに止らずOーア セチル化を奶げる作用があるとしなくてはならない．

更にこの反㗹の普遍性を調べるために aminodiol (I) を義酸, メントキシ酶酸, マンデル酸とともに夫ふブ タフール中で加熱したところ各《から $N$-formylaminodiol (IX) $\mathrm{mp} 180^{\circ}, N$-menthoxyacetylaminodiol (X)

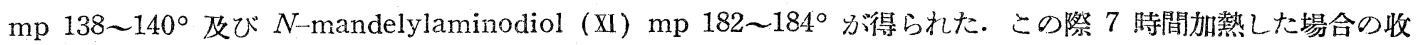

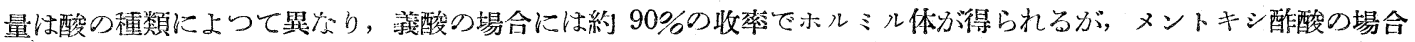

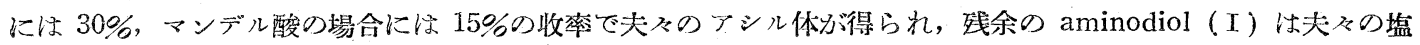
(XII), (XIII) として回收された.
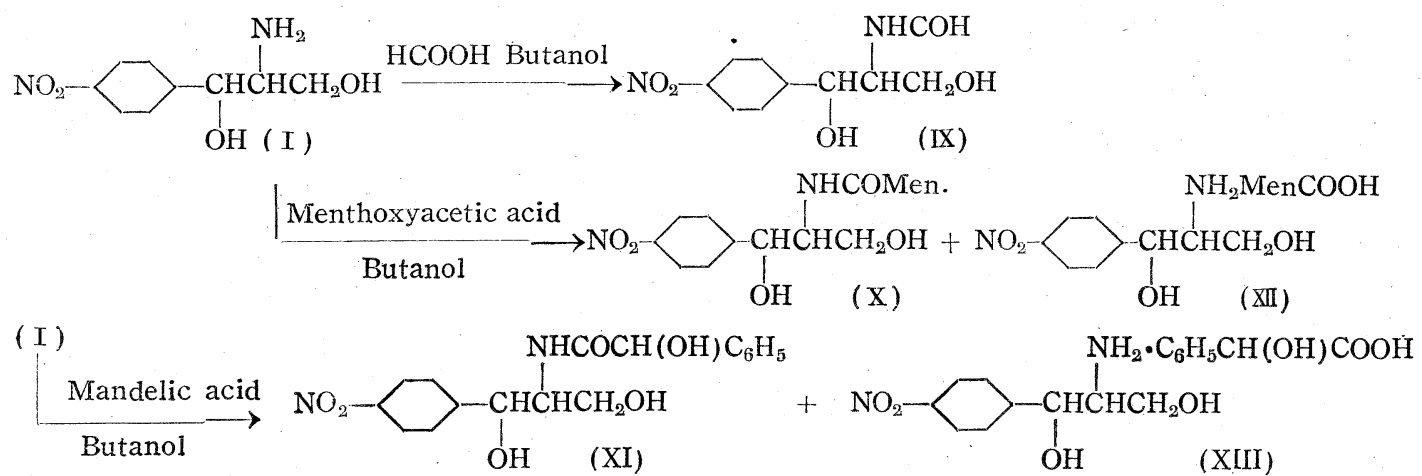

更に芳香族の酸の例として安息香酸をとり aminodiol (I) とブタノール中で加熱したところ，この場合には aminodiol の安息香酸塩 (XIV) が得られたの々で $N$-benzoylaminodiol (XV) の生成は認められず, aminodiol (I) を安息香酸と 130 140。 (外温)に加熱熔融することにより初めて $N$-benzoylaminodiol (XV) が生 成し，一部の aminodiol (I) は安息香酸塩 (XIV) として回收された.

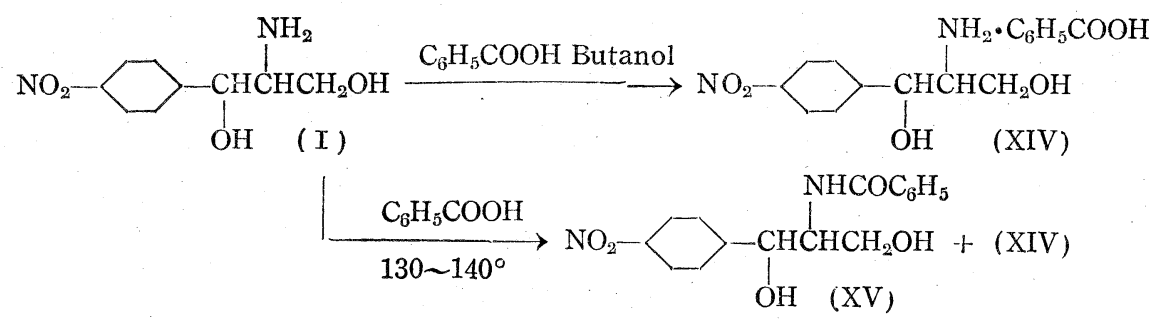


これらの結果起考察すると， aminodiol（I）起酸 1 モルと加熱する場合には溶媒の如何に拘らず先ずそれぞれ の酸の塩が生成し，次に塩の脫水か起つて $N$-アシル化が行われ，酸が過剩の場合には溶媒を用いない場合又は、卜 ルェンのよ5な溶媒を用いた場合には酸の種類によつて更にアシル化が進行して $N, O$-ジアシル化文は $N, O, O$ トリアシル化が起り，ブタノールの存在に捛いては酸が過剩の場合にも $O$-アシル化ぶ防止されて常に $N$ ーアシル 体のみ生成すると考えられる。Oーアシル化の行われ蜼い原无がブタノールの存在によつて安息香酸の場合の上5 にアシル化の作用が，減弱されるためか，㚣るいはジクロル醀酸の場命のよ5にブタノールが aminodiol (I) よりもェステル化され易い為に先ずブテルェステルが生成されて，ジクロル釄酸起消費してしま5ためで女るか は㨁ちに結論出來ない.

又酸の種類とアシル体の收率との関係は酸の强度と本行性が見出されない，例之ば上例で水溶夜及びブタノー

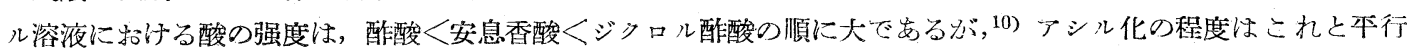
していない，今のところ予想されることは，酸による $N$ ーアシル化については: アミン体と酸との塩の形成とい らこととその塩の脫水といらこととはそれぞれ別な因子で爷眼されているだろらと云らことである.

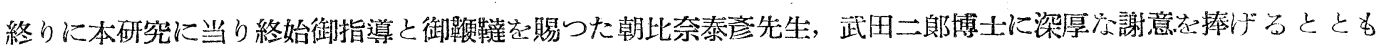
に, 本研究の機会を與えられ終始御指導と御激励七賜り本交の御校閱さ賜つた研究所長桑田智博士並びに主任研 究員立岡末雄博士に深基な感謝起捧げる. 佮元素分析の労起執られた管, 鈴木, 小林, 中田, 柏木の諸氏に深謝 劣。

\section{実験 の、部}

$d l-N, O, O$-Tri(dichloroacetyl) -1- $p$-nitrophenyl-2-amino-1,3-propanediol(IV) ( $d l-N, O, O$-Tri (dichloroacetyl)-aminodiol (IV)) i) aminodiol (I) $3 \mathrm{~g}$ にジクロル醀酸 $10 \mathrm{cc}$ を加元, 外溫 $130 〜 140^{\circ} に 7$

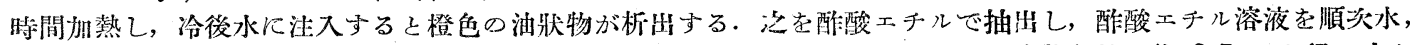

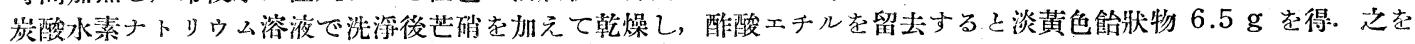

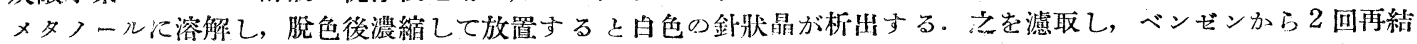

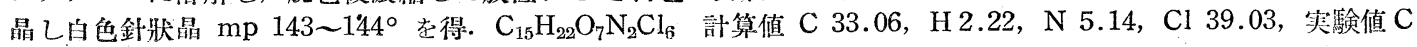
$33.06, \mathrm{H} 3.00, \mathrm{~N} 5.70, \mathrm{Cl} 39.63$.

ii) $d l$-aminodiol ( I) $0.5 \mathrm{~g}(1 / 400$ モル) Кジクロル酶酸 $1 \mathrm{~g}(3 / 400$ モル) とトルェン $5 \mathrm{cc}$ を㞦え，8 時開劣沸すると均一な溶液を得. トルエンを減压下に留去し残留物に少量のメタノ一ルを加えると白色針狀晶が

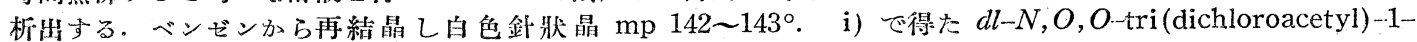
p-nitrophenyl-2-amino-1,3-propanediol (IV) (mp 142-143) こ混融して融点降下せず.

$d l$-1-p-Nitrophenyl-2-dichloroacetamino-1,3-propanediol (II) (dl-Chloramphenicol (II)) i) $d l$ aminodiol (I) $1.1 \mathrm{~g}$ (1/200 モル) トジクロル酢酸 $0.7 \mathrm{~g}$ (1/200 モル) を加元,ブタノール5 cc 中で 8 時間者沸した後減圧でブタノールを留去すると飴狀物が残留する。之を酶酸エチルル溶解し，3回水洗後芒硝で

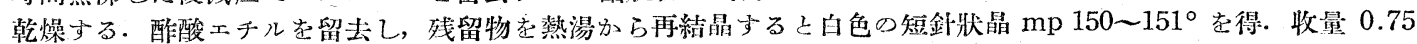
$\mathrm{g}(47 \%)$. 佾水洗を强アルカリ性にするこ $d l$-aminodiol (I) $0.55 \mathrm{~g}$ (回收率 $50 \%$ ) を回收する.

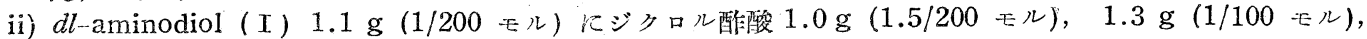
$2.0 \mathrm{~g}(3 / 200$ モル) を加え, 夫タブタノール $5 \mathrm{cc}$ 中で 8 時間煮沸後減圧下でブタノールを留去するとジクロル

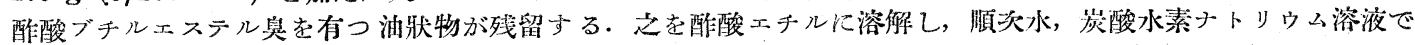

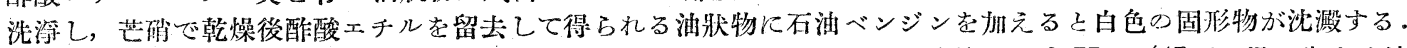

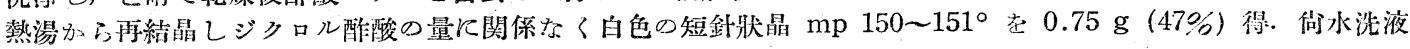
をアルカリ性にすると $d l$-aminodiol (I) を回收する. $0.55 \mathrm{~g}$ (四收率 $50 \%$ ).

iii) al-aminodiol dichloroacetate (III) $0.7 \mathrm{~g}(1 / 500$ モル) とブタノール $4 \mathrm{cc}$ を加え, 7 時間省沸後i)を

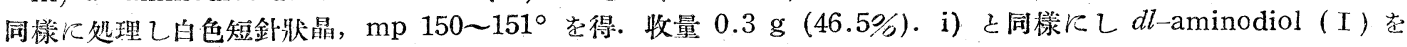
回收与ち.

iv) $d l$-aminodiol $1.1 \mathrm{~g}(1 / 200$ モル) Кジクロル酢酸 $0.7 \mathrm{~g}(1 / 200$ モル) を加えトルェン $5 \mathrm{cc}$ 中で 8

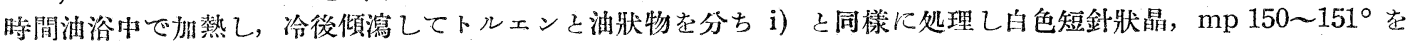

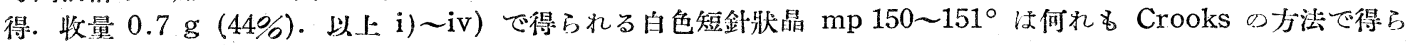

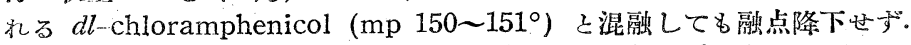

$d l$-1-p-Nitrophenyl-2-amino-1,3-propanediol dichloroacetate (III) ( $d l$-Aminodiol dichloroacetate

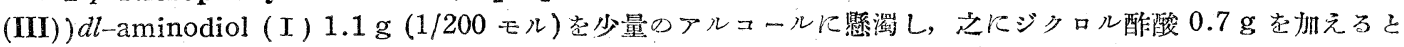

10) L. A. Wooten, L. P. Hammett: J. Am. Chem. Soc. 57, 2293 (1935). 


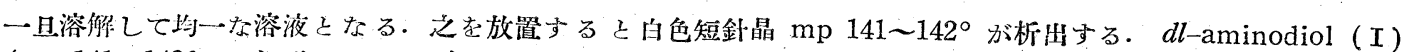
$\left(\mathrm{mp} \mathrm{141} \sim 142^{\circ}\right)$ と混融与れば融点降下を示与（混融溫度 $113 \sim 125^{\circ}$ )。 $\quad \mathrm{C}_{11} \mathrm{H}_{14} \mathrm{O}_{6} \mathrm{~N}_{2} \mathrm{Cl}_{2}$ 計算值 $\mathrm{C} 38.72, \mathrm{H}$ $4.14, \mathrm{~N} 8.21$, 实験值 C 38.54, H 4.16, N 8.075.

$d l$-1-p-Nitrophenyl- 2 -acetylamino- 3 -acetoxypropane- 1 -ol (VIII) ( $d l$-O, $N$-diacetylaminodiol

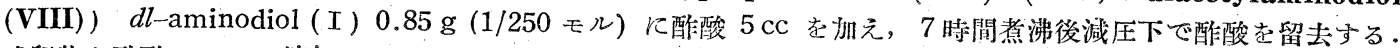

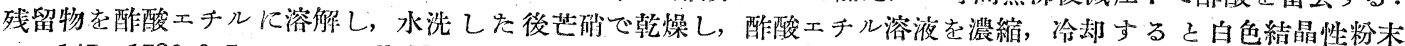

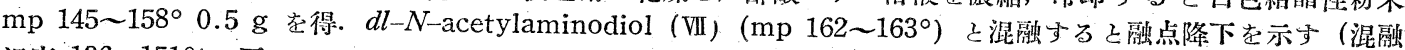
溫度 $136 \sim 151^{\circ}$ ). 更にメタノールから再結晶し白色針狀晶 mp 164 168 皇得. dl- $O, N$-diacetylaminodiol

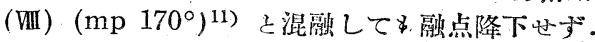

$d l$-1-p-Nitrophenyl-2-acetylamino-1,3-propanediol (VII) (dl-N-Acetylaminodiol (VII)) i) 酷酸

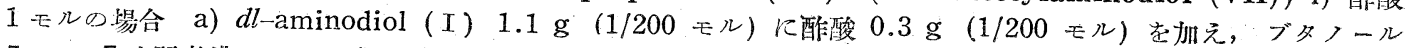
$5 \mathrm{cc}$ ¿ 7 時間者沸した後, 減圧でブタノールを留去すると白色結晶性粉未を得. 之酢酸エチルで処理し, 不溶

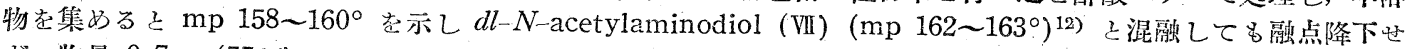
ず. 收量 $0.7 \mathrm{~g}(55 \%)$.

b) $d l$-aminodiol (I) $1.1 \mathrm{~g}$ (1/200 モル) に酶陌夋 $0.3 \mathrm{~g}(1 / 200$ モル) を加えトルェン中で 7 時間煮沙し,

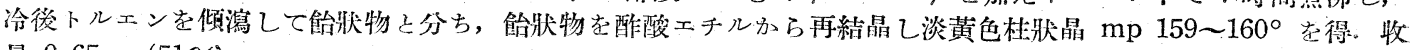
量 $0.65 \mathrm{~g}(51 \%)$.

ii) 酢酸 5 モルの場合 a) $d l$-aminodiol ( I ) $0.4 \mathrm{~g}(1 / 500$ モル) に醀酸 $0.6 \mathrm{~g}(1 / 100$ モル) を加え，ブ

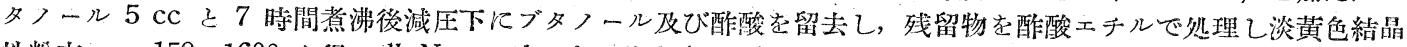

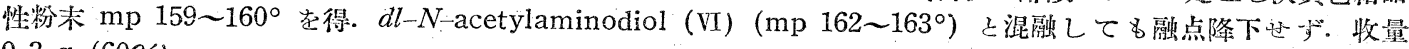
$0.3 \mathrm{~g}(60 \%)$.

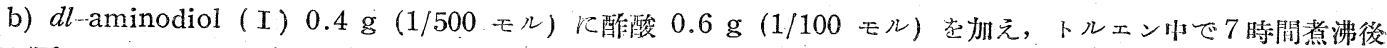
減圧下でトルェン及び酶酸を留去し, 残留物に酢酸エチルを加えると融点の不鮮明大結晶を得. 更に酢酸エチル

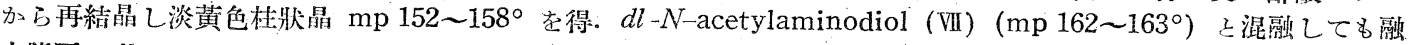
点降下过す。。

$d l$-1-p-Nitrophenyl-2-formylamino-1,3-propanediol (IX) ( $N$-Formylaminodiol (IX)) $d l$-aminodiol $0.3 \mathrm{~g}(0.3 / 200$ モル) に義酸 $0.3 \mathrm{cc}(1 / 150$ モル) を加え, ブタノール $2 \mathrm{cc}$ 中て 5 時閒者沸後減圧下に

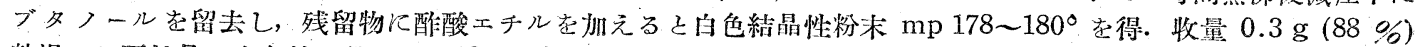

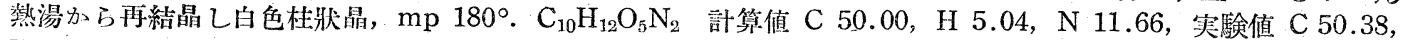
H 5.17, N 11.78 .

$d l$-1-p-Nitrophenyl-2-menthoxyacetylamino-1,3-propanediol $(\mathbf{X})(N$-Menthoxyacetylaminodiol (X)) $d l$-aminodiol $l$-menthoxyacetate (XII) $1 \mathrm{~g}$ にブタノール $5 \mathrm{cc}$ を加えて 7 時聞加熱した後, ブタノール を減圧で留去し, 残留物を醡酸エチルに溶解し, 順次水, 希塩酸, 炭酸水素ナトリウム溶液で洗浮後芒䂙で乾燥 乙, 酢酸エチルを濃縮し白色桂狀晶, $\mathrm{mp} 138 \sim 140^{\circ} 0.3 \mathrm{~g}(30 \%)$ を得. $\mathrm{C}_{21} \mathrm{H}_{32} \mathrm{O}_{6} \mathrm{~N}_{2}$, 計算值 $\mathrm{C} 61.74, \mathrm{H} 7.90$,

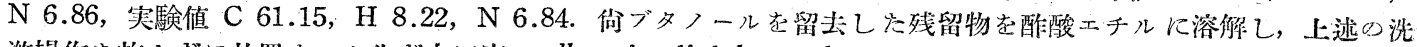
滌操作を施さずに放置すると先ず末反應の $d l$-aminodiol $l$-menthoxyacetate (XII) 回收する. 去熱湯から

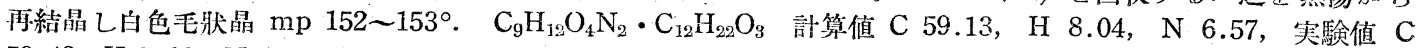
59.48, H 7.92，N 6.34. 之を N-menthoxyacetylaminodiol (X) (mp 138〜140 ) と湿融すると融点降下を 示少 (混融溫度 $122 \sim 128^{\circ}$ ).

$d l$-1-p-Nitrophenyl-2-amino-1,3-propanediol- $d l$-mandelate (XIII) ( $d l$-Aminodiol-dl-mandelate (XIII)) $d l$-aminodiol ( I ) $0.5 \mathrm{~g}$ (1/400 モル) にdl-マンデル酸 $0.4 \mathrm{~g}$ (ca. 1/400 モル)を加え，フルコー

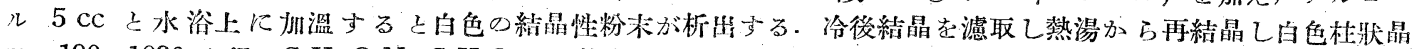

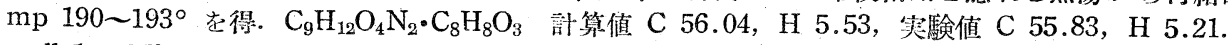

$d l-1-p$-Nitrophenyl-2-mandelylamino-1,3-propanediol (XI) (N-Mandelylaminodiol (XI)) $d l$ aminodiol (I) $0.5 \mathrm{~g}$ (1/400モル) Kdlールマンデル酸 $0.8 \mathrm{~g}$ (1/200モル) を加え, ブタノール $5 \mathrm{cc}$ 巾で

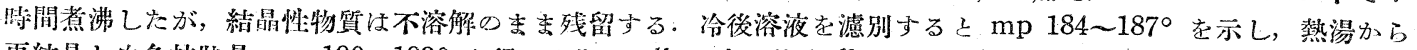

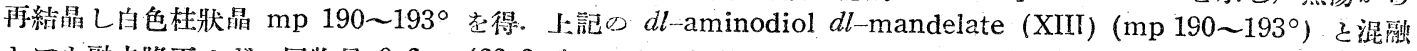
しても融点降下せず・回收量 $0.6 \mathrm{~g}(66.6 \%)$.上記の結晶を滤別した濾液から減圧でブタノ一ルを留去し，殘留

11) 標品として混融に使成した $d l-O, N$-diacetylaminodiol (纤) は Crooks 等3) が 1-phenyl-2-acetylamino-3-acetoxypropane-1-ol を製した方法に準拠して $d l-1-p$-nitrophenyl-2-acetylamino-1,3-propane-

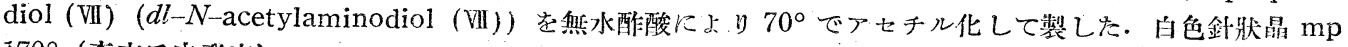
$170^{\circ}$ (森本氏米発表).

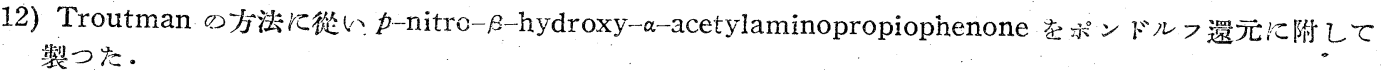




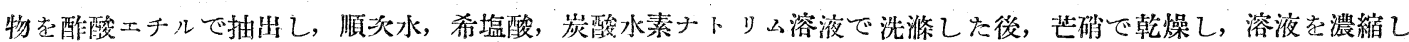
mp 180 1840 の結晶分析出する. 收量 $0.12 \mathrm{~g}$ (14\%). メタノールから再結晶乙白色板狀晶, $\mathrm{mp} 182 \sim 184^{\circ}$

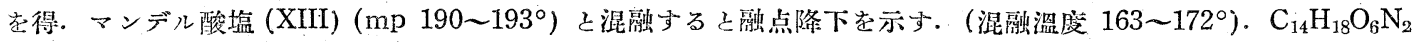
計算值 C 58.95, H 5.24, 实験值 C 59.31, H 5.24.

$d l$-1-p-Nitrophenyl-2-amino-1,3-propanediol benzoate (XIV) ( $d l$-Aminodiol benzoate (XIV)) $d l$ aminodiol (I) $0.5 \mathrm{~g}$ (1/400 モル) に努息香酸 $0.6 \mathrm{~g}$ (1/200 モル) を加えブタノール $5 \mathrm{cc}$ 中で 7 時間加熱

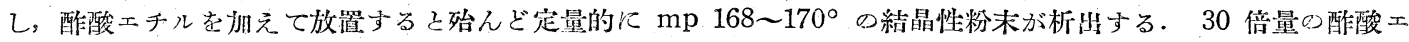

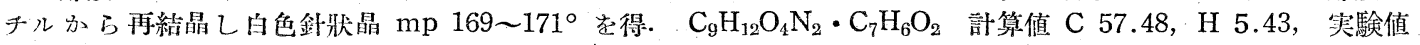
C 57.48 , H 5.75 .

$d l$-1-p-Nitrophenyl-2-benzoylamino-1,3-propanediol (XV) ( $N$-Benzoyl-aminodiol (XV)) $d l$ aminodiol (I) $1.1 \mathrm{~g}$ (1/200 モ几) K安息香酸 $1.5 \mathrm{~g}$ (1.2/100 モル) を加元覺拌しつつ外溫 $130 \sim 140^{\circ}$ に 3

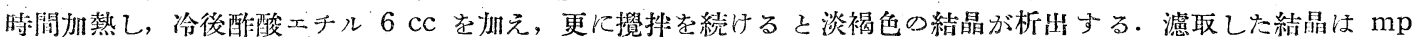

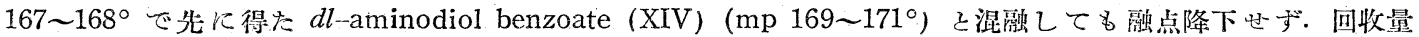

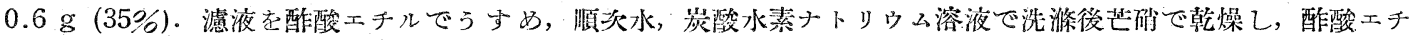

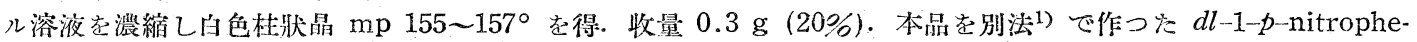
nyl-2-benzoylamino-1,3-propanediol (XV) (mp 157 159) こ混融しても融点降下せず:

武田薬品工業株式会嶇:

\section{Summary}

By heating 1-p-nitrophenyl-2-amino-1,3-propanediol (aminodiol) (I) with an excess of dichloroacetic acid by themselves at $130-140^{\circ}$ or in toluene, $N, O, O$-tri (dichloroacetyl)aminodiol, m. p. $142-143^{\circ}$, is obtained. In the case of heating in butanol, $N$-dichloroacetylaminodiol (chloramphenicol), m. p. $150-151^{\circ}$, is obtained in a $47 \%$ yield irrespective of the amount of dichloroacetic acid used. Boiling aminodiol with an excess of acetic acid gives $N, O$-diacetylaminodiol, m. p. $170^{\circ}$, while heating with equimolar amount of acetic acid in toluene, or with 1-5 molar quantity of acetic acid in butanol gives $N$-acetylaminodiol, m. p. $162-163^{\circ}$, in $50-60 \%$ yield. Heating (I) in butanol with formic, menthoxyacetic and mandelic acids in butanol gives, respectively, $N$-formylaminodiol, m. p. $180^{\circ}$, in $80-90 \%$ yield, $N$-menthoxyacetylaminodiol, m. p. $138-140^{\circ}$, in $30 \%$ yield, and $N$-mandelylaminodiol, m. p. $182-184^{\circ}$, in $15 \%$ yield. Heating (I) with excess of benzoic acid at $130-140^{\circ}$ gives $N$-benzoylaminodiol. From these results, it is seen that, although the yields vary according to the acid used, heating aminodiol with organic acid in butanol results in selective $N$-acylation, the reaction mechanism of which is assumed to be dehydration of organic salts of aminodiol. 